\title{
Anthoceros-Nostoc Symbiosis: Immunoelectronmicroscopic Localization of Nitrogenase, Glutamine Synthetase, Phycoerythrin and Ribulose-1,5-bisphosphate Carboxylase/Oxygenase in the Cyanobiont and the Cultured (Free-living) Isolate Nostoc 7801
}

\author{
By A. N. RAI, ${ }^{*}$ M. BORTHAKUR, ${ }^{1}$ S. SINGH ${ }^{1}$ AND B. BERGMAN ${ }^{2}$ \\ ${ }^{1}$ Department of Biochemistry, North-Eastern Hill University, Shillong 793014, India \\ ${ }^{2}$ Department of Physiological Botany, University of Uppsala, Box 540, S-75121 Uppsala, Sweden
}

(Received 6 July 1988; revised 29 September 1988; accepted 26 October 1988)

Localization of nitrogenase, glutamine synthetase (GS), phycoerythrin (PE) and ribulose1,5-bisphosphate carboxylase/oxygenase ( $\mathrm{RuBisCO})$ was studied with immunocytochemical techniques in the cyanobiont and the free-living cultured isolate Nostoc 7801 of Anthoceros punctatus. In both cases nitrogenase was located in heterocysts only and was uniformly distributed within the cell. GS was located both in heterocysts and vegetative cells, with a uniform cellular distribution in each cell type. Whereas heterocysts of Nostoc 7801 had about twofold higher label than vegetative cells, labelling in heterocysts and vegetative cells of the cyanobiont was similar. While the GS content of the vegetative cells of the cyanobiont and Nostoc 7801 was comparable, the apparent GS content of the cyanobiont heterocysts was $60 \%$ less than that in Nostoc 7801 heterocysts. PE and RuBisCO were located in vegetative cells only. $\mathrm{PE}$ was located on thylakoid membranes and $\mathrm{RuBisCO}$ in the cytoplasm and carboxysomes. In each case the pattern of labelling in the cyanobiont and Nostoc 7801 was similar.

\section{INTRODUCTION}

$\mathrm{N}_{2}$-fixing cyanobacteria form symbiotic associations with plants that range from algae to angiosperms (Gallon \& Chaplin, 1987; Smith \& Douglas, 1987). The cyanobacterial partner (cyanobiont) in all these symbioses is known to fix $\mathrm{N}_{2}$ and make fixed nitrogen available to the eukaryotic partner (see Stewart et al., 1983). In some symbioses (e.g. in lichens and Azolla) the cyanobiont is photosynthetically active. However, in bryophytes, cycads and Gunnera, the cyanobiont is photosynthetically inactive and dependent on the eukaryotic partner for its fixed carbon (Smith \& Douglas, 1987; Stewart et al., 1983). The transfer of metabolites between the cyanobiont and eukaryotic partner is linked to physiological and biochemical changes in the cyanobiont (Stewart et al., 1983; Meeks et al., 1985; Nierzwicki-Bauer \& Haselkorn, 1986; Lindblad et al., 1987).

Among the bryophyte-cyanobacterial symbioses, the hornwort Anthoceros-Nostoc symbiosis is best characterized. $\mathbf{N}_{2}$-fixing Nostoc spp. develop in cavities on the undersurface of the Anthoceros gametophyte thallus. The cyanobiont in this association reportedly has an increased heterocyst frequency, is photosynthetically inactive and lacks phycobiliproteins (Rodgers \& Stewart, 1977; Stewart \& Rodgers, 1977). The increased heterocyst frequency does not correlate with an increase in $\mathrm{N}_{2}$-fixation rates (Rodgers \& Stewart, 1977; Stewart \& Rodgers, 1977). Whether this is due to limited availability of fixed carbon or to the presence of nonfunctional heterocysts lacking nitrogenase is not known. The activity of glutamine synthetase (GS) in the

Abbreviations: GS, glutamine synthetase; GDH, glutamic dehydrogenase; PE, phycoerythrin; RuBisCO, ribulose-1,5-bisphosphate carboxylase/oxygenase; TEM, transmission electronmicroscopy. 
cyanobiont is three- to fourfold lower than that in the free-living isolate; this reduction is apparently due to regulation at the level of enzyme inactivation rather than synthesis (Joseph \& Meeks, 1987). This is in contrast to the situation in lichen and Azolla cyanobionts, where the reduction in GS activity has been attributed to low rates of enzyme synthesis (Stewart et al., 1983; Rowell et al., 1985; Nierzwicki-Bauer \& Haselkorn, 1986). The relative distribution of GS between vegetative cells and heterocysts of the cyanobiont in Anthoceros is not known.

Using immunocytochemistry, the aims of this study were (1) to examine the content of GS protein and its relative distribution between heterocysts and vegetative cells, and (2) to check for the presence of nitrogenase, phycoerythrin (PE) and ribulose-1,5-bisphosphate carboxylase/ oxygenase $(\mathrm{RuBis} C \mathrm{O})$ in vegetative cells and in single and multiple heterocysts in the cyanobiont from mature cyanobacterial colonies of the Anthoceros punctatus gametophyte. For comparison, the free-living cultured isolate Nostoc 7801 was also studied.

\section{METHODS}

Organisms. Nostoc sp. strain 7801 was obtained from Dr J. C. Meeks (Department of Bacteriology, University of California, Davis, USA). Axenic batch cultures were grown in BG-11 $1_{0}$ medium (Rippka et al., 1979) at $25^{\circ} \mathrm{C}$ and at a photon fluence rate of $70 \mu \mathrm{mol} \mathrm{m} \mathrm{m}^{-2} \mathrm{~s}^{-1}$. Anthoceros punctatus gametophyte thalli bearing cyanobacterial colonies were collected from North-Eastern Hill University campus (Shillong, India) at the end of September, at around 11 a.m. The thalli were cleaned using distilled water and mature colonies from middle portions of the thalli were picked using a needle and fine forceps.

Antibodies. Rabbit serum containing antibodies raised against Fe-protein of nitrogenase (dinitrogenase reductase), purified from Rhodospirillum rubrum, was a gift from Dr S. Nordlund (University of Stockholm, Stockholm, Sweden) and has been previously used for specific localization of nitrogenase in free-living and symbiotic cyanobacteria (Bergman et al., 1986). Antibody against GS protein, purified from Anabaena PCC 7120, was a gift from Professor R. Haselkorn (University of Chicago, Chicago, USA); it has been shown to be monospecific, and has been used for GS localization in cyanobacteria (Orr \& Haselkorn, 1982; Bergman et al., 1985). Antibodies against PE, purified from the cyanobacterium Phormidium persicinum, were a gift from $\mathrm{Dr} D$. Guard-Friar and its specificity has been shown by Guard-Friar $e t$ al. (1986). These antibodies were also seen to be specific from the labelling pattern observed, i.e. high labelling in thylakoids of vegetative cells and comparatively little labelling in heterocysts, which are known to have little or no phycobiliproteins (see Stewart, 1980).

Rabbit serum containing antibodies raised against RuBisCO purified from Sinapis alba was a gift from Dr R. Oelmüller (University of Freiburg, Freiburg, FRG). The antibodies have been shown to be specific against chloroplast RuBisCO (Oelmüller \& Mohr, 1986). Their specificity with cyanobacterial RuBisCO was assumed, indirectly, from the labelling pattern observed, i.e. high labelling in vegetative cells, particularly carboxysomes (which are known to be RuBisCO-containing bodies in cyanobacteria), and very low labelling in heterocysts. This pattern of labelling is identical to that observed using $\mathrm{RuBisCO}$ antibodies raised against the enzyme purified from cyanobacteria (see Cossar et al., 1985).

Immunolabelling and transmission electron microscopy (TEM). Preparation of samples for TEM and the protocols for immunolabelling were essentially as described by Bergman et al. (1985) except that uncoated gold grids were used, the goat anti-rabbit IgG was conjugated to $15 \mathrm{~nm}$ size colloidal gold particles and different primary antibodies were used as required (see figure legends). Ultrathin sections of glutaraldehyde-fixed and Eponembedded samples were cut with an LKB Ultramicrotome and picked up on gold grids ( $300 \mu \mathrm{m}$ mesh). These were then labelled for $1 \mathrm{~h}$ with primary antibody (rabbit anti-nitrogenase, GS, PE or RuBisCO) followed by $30 \mathrm{~min}$ incubation with secondary antibody (goat anti-rabbit IgG conjugated to $15 \mathrm{~nm}$ size colloidal gold particles). After cross-reaction, the sections on grids were stained with uranyl acetate and lead citrate. TEM observations were made using a Jeol $100 \mathrm{~B}$ electron microscope operated at $60 \mathrm{kV}$. Five ultrathin sections from three mature Nostoc colonies from Anthoceros punctatus gametophyte were used in each labelling experiment. However, except for GS, where 15 electronmicrographs were taken, only five or six electronmicrographs were taken. We present one set of representative micrographs, for each labelling experiment, which we assume refiect the functional symbiosis.

\section{RESULTS AND DISCUSSION}

Biochemical characterization of the cyanobiont has been rather difficult because of the problem of obtaining enough clean material from the symbiotic association. Furthermore, in isolating the cyanobiont, whole thalli are generally used. This results in metabolically heterogeneous cyanobiont populations since cyanobionts are in different stages of developing symbiosis in different parts of the thallus, as indicated by varying heterocyst frequency and 
enzymic activities (see Englund, 1977; Lindblad et al., 1985; Rowell et al., 1985). With the introduction of immunogold labelling these problems can be avoided and an antigen can be located precisely with little sample material. Here, we have used this method to study the Anthoceros-Nostoc association in mature cyanobacterial colonies from the mid-part of the $A$. punctatus thallus.

The secondary antibody (goat anti-rabbit IgG) was first tested for any nonspecific binding to the fixed cells. Virtually no label was detected in the absence of the primary antibody either in the cyanobiont or in Nostoc 7801 (Fig. $1 a, b$ ). This showed that the antibody was specific to rabbit IgG. The location of the specific antigens was then determined using primary antibodies to nitrogenase, GS, PE and RuBisCO.

\section{Nitrogenase}

In heterocystous cyanobacteria, nitrogenase is restricted to heterocysts under aerobic growth conditions (Stewart, 1980; Janaki \& Wolk, 1982). However, nitrogenase may be expressed in vegetative cells of non-heterocystous cyanobacteria both under microaerobic (Stewart \& Lex, 1970; Rippka \& Waterbury, 1977) and aerobic (Stal \& Krumbein, 1985) conditions. Whether nitrogenase can be induced in vegetative cells of heterocystous cyanobacteria is less certain (Flemming \& Haselkorn, 1974; Murry et al., 1984). Rippka \& Stanier (1978) and Spence \& Stewart (1987) isolated mutants of Anabaena lacking heterocysts in which $\mathbf{N}_{2}$-fixation still occurs. Bergman et al. (1986) have shown that in lichens and in root nodules of cycads, nitrogenase is restricted to heterocysts only. However, the possibility of $\mathbf{N}_{2}$-fixation in vegetative cells of the cyanobiont in Anthoceros-Nostoc symbiosis has been suggested (Rodgers \& Stewart, 1977).

Immunolabelling experiments on the cyanobiont of $A$. punctatus showed that the nitrogenase was located in heterocysts only (Fig. $2 a$ ). The pattern and intensity of labelling was similar in the free-living Nostoc 7801 (Fig. 2b). The distribution of the antigen within the heterocysts was uniform. Labelling in vegetative cells was very low, suggesting that they contained little or no nitrogenase.

As in the Nostoc cyanobiont of lichens (Englund, 1977) and cycads (Lindblad et al., 1985), the heterocyst frequency of the cyanobiont in bryophytes can vary with the age of the colony (Rodgers \& Stewart, 1977). A maximum heterocyst frequency of $43 \%$, as against 3-6\% in the free-living Nostoc, has been observed in the cyanobiont of Anthoceros (Rodgers \& Stewart, 1977). However, the increase in nitrogenase activity was much less than the increase in heterocyst frequency (Rodgers \& Stewart, 1977), indicating the presence of nonfunctional heterocysts. Immunogold labelling showed that all the heterocysts of the cyanobiont, including the multiple ones, contained the nitrogenase protein (Fig. $2 a, b$ ). This suggests that the supply of fixed carbon to multiple heterocysts occurring in chains may be restricted. A similar case has been found in the cycad cyanobiont (Bergman et al., 1986). Although the photosynthate is provided by the eukaryotic partner in Anthoceros (Rodgers \& Stewart, 1977), it probably enters the heterocysts via the vegetative cells. Heterocysts with no direct contact with the vegetative cells may receive little or no fixed carbon. In the cycad cyanobiont, an increase in nitrogenase activity correlates with an increase in the frequency of single heterocysts throughout the root (tip to base), but with increasing number of multiple heterocysts this correlation is lost (Lindblad et al., 1985).

\section{Glutamine synthetase}

GS (EC 6.3.1.2) is the primary ammonia-assimilating enzyme in heterocystous cyanobacteria (see Stewart, 1980). In lichens, Azolla and hornwort symbioses the GS activity in the cyanobiont is reduced, which may contribute to the liberation of $\mathrm{N}_{2}$-derived ammonia from the cyanobiont (see Stewart et al., 1983; Meeks et al., 1985).

In the Anthoceros-Nostoc association, GS activity in the cyanobiont has been reported to be reduced three- to fourfold without a similar decrease in the GS content (Joseph \& Meeks, 1987). This led to the conclusion that GS activity in the cyanobiont is regulated by a post-translational mechanism. However, the relative distribution of the inactive GS protein between heterocysts and vegetative cells is not known. 

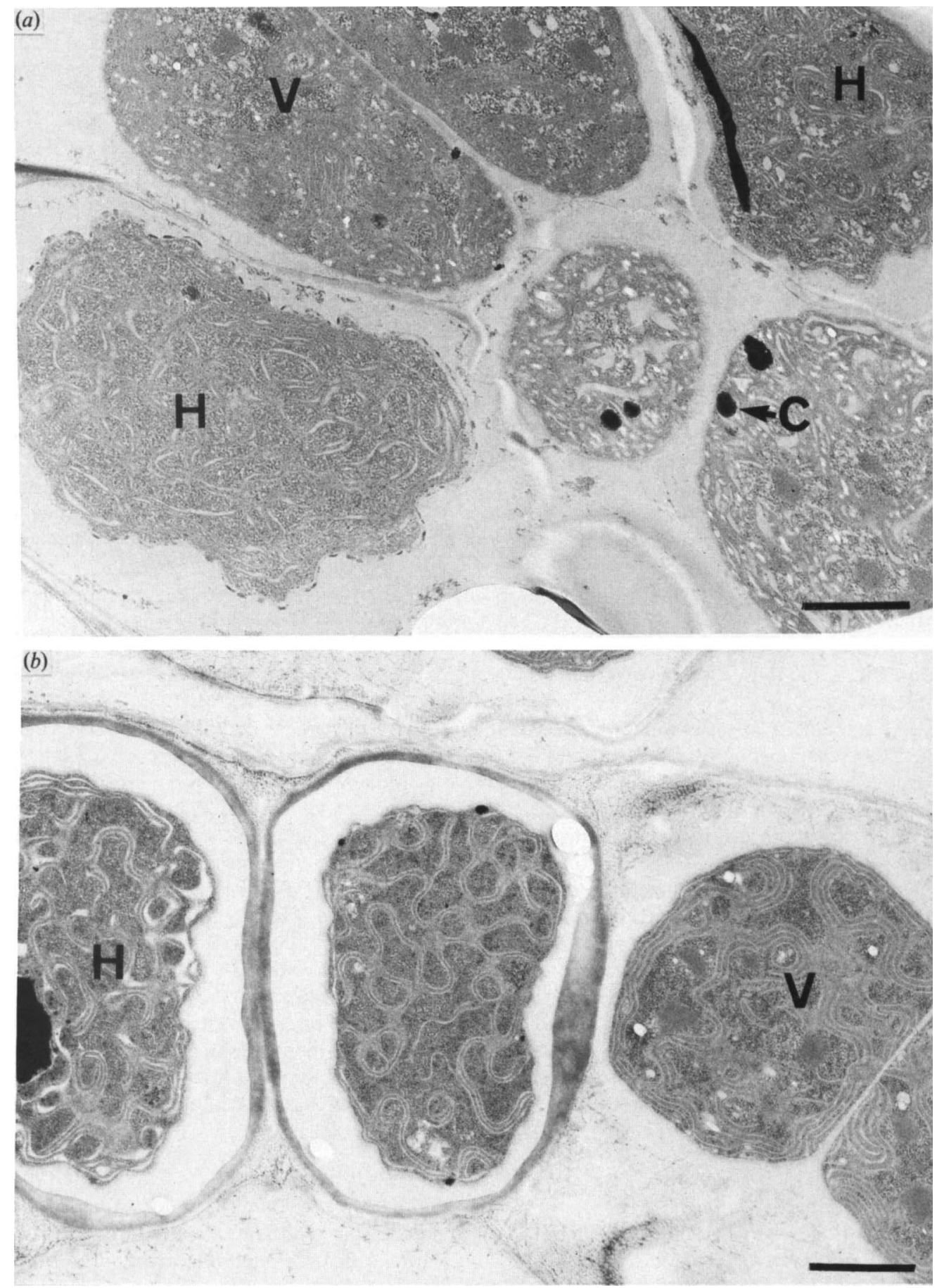

Fig. 1. Background (unspecific) labelling due to secondary antibody (goat anti-rabbit IgG, gold conjugated) in the cyanobiont $(a)$ and in the free-living cultured isolate Nostoc $7801(b)$. In these experiments primary antibody was omitted during immunolabelling. V, Vegetative cells; $H$, heterocysts; C, cyanophycin. Bar marker, 1 micrometer. 

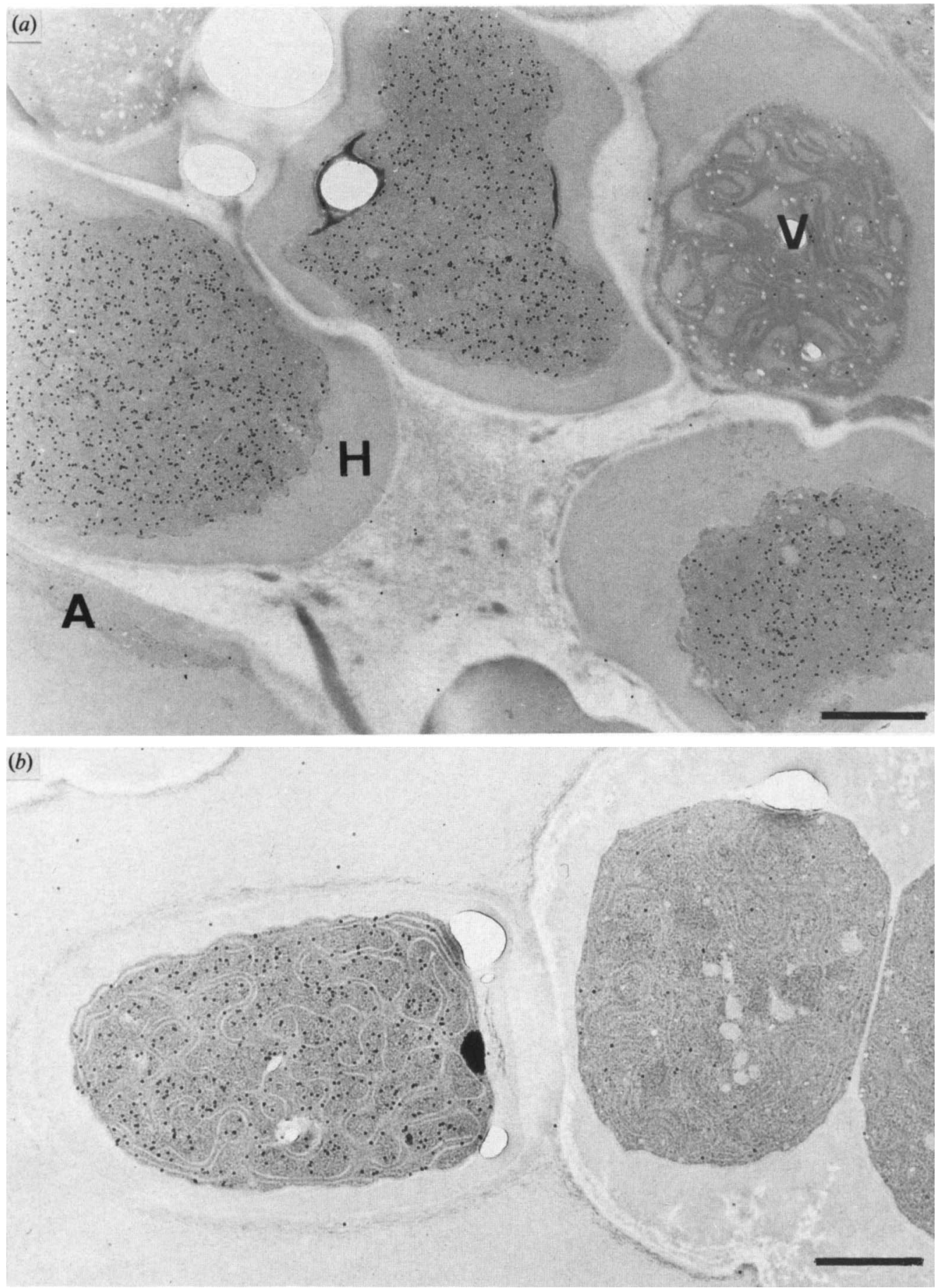

Fig. 2. Localization of nitrogenase in the cyanobiont $(a)$ and in the free-living cultured isolate Nostoc 7801 (b). Rabbit anti-Rhodospirillum rubrum nitrogenase (Fe-protein) was used as the primary antibody. Other details as in Fig. 1; A, Anthoceros tissue. 

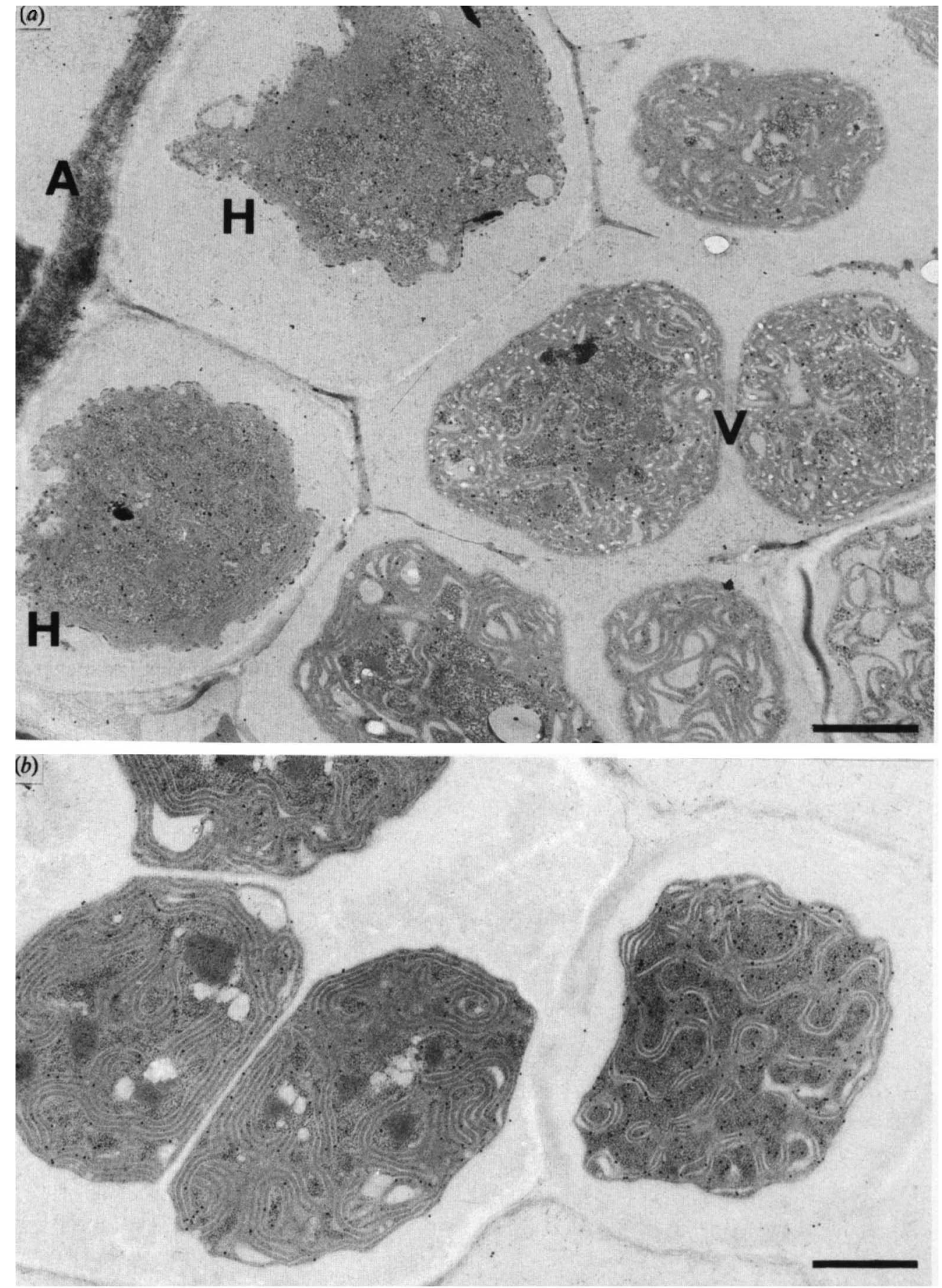

Fig. 3. Localization of GS in the cyanobiont ( $a$ ) and in the free-living cultured isolate Nostoc $7801(b)$. Rabbit anti-Anabaena 7120 GS was used as primary antibody. Other details as in Figs 1 and 2. 
Table 1. GS content of heterocysts and vegetative cells of the cyanobiont and the free-living cultured isolate Nostoc 7801 from Anthoceros punctatus

The GS contents given below are comparative and were calculated by counting the number of gold particles per unit cell area using TEM photomicrograph prints (at $\times 15000$ magnification). The data are means \pm SE of 70 counts from 15 photomicrographs taken from five ultrathin sections of three symbiotic colonies.

Sample No. of gold particles $\mathrm{cm}^{-2}$

Nostoc 7801

Vegetative cells
Heterocysts

$8.21 \pm 1.35$

Cyanobiont

Vegetative cells

$17.30 \pm 3.65$

Heterocysts

$6.96 \pm 1.30$

$7 \cdot 15 \pm 1 \cdot 71$

The GS protein was present in both heterocysts and vegetative cells (Fig. $3 a, b$ ) and its distribution was uniform within the cells. As in other free-living cyanobacteria (Bergman et al., 1985), labelling in Nostoc 7801 heterocysts was nearly twofold higher than that in vegetative cells (Fig. $3 b$, Table 1). In contrast, the label in the cyanobiont was similar in heterocysts and vegetative cells (Fig. $3 a$, Table 1). Multiple heterocysts also contained similar amounts of the label. The GS content was similar in vegetative cells of the cyanobiont and Nostoc 7801 but the cyanobiont heterocysts had $60 \%$ less GS protein than the heterocysts of Nostoc 7801 . Thus, reduction in GS activity of the cyanobiont is at least partly due to a reduction in the GS content of heterocysts. This contrasts with the situation in lichens and Azolla, where reduction in GS activity is due only to decreased synthesis of GS (see Stewart et al., 1983; Nierzwicki-Bauer \& Haselkorn, 1986). It also differs from the cycad cyanobiont, which has full GS activity and normal GS content, with a distribution pattern in heterocysts and vegetative cells similar to that in heterocysts and vegetative cells of the free-living isolate (Lindblad \& Bergman, 1986). However, the selective decrease in GS content in heterocysts noted here resembles the situation in lichens (Hällbom et al., 1986) and Azolla (B. Bergman, unpublished results), where the distribution of residual GS in the cyanobiont is similar in both heterocysts and vegetative cells. It is interesting to note here that when $\mathrm{N}_{2}$-grown cultures of Anabaena cylindrica are transferred to ammonium medium, the few heterocysts which remain show a GS content similar to that of vegetative cells (E. Renström, unpublished results).

\section{Phycoerythrin}

Phycobiliproteins are accessory photosynthetic pigments in cyanobacteria. They also serve as a nitrogen reserve and undergo degradation during nitrogen limitation (Cohen-Bazire \& Bryant, 1982; Ho \& Krogman, 1982). The cyanobionts in lichens, Azolla and cycads possess phycobiliproteins (see Stewart et al., 1983; Lindblad, 1987). However, Stewart \& Rodgers (1977) were unable to detect phycobiliproteins in the cyanobiont of Anthoceros punctatus, although structures similar to phycobilisomes were noted in their TEM photomicrographs.

Immunolabelling experiments showed that PE is present in the cyanobiont of $A$. punctatus (Fig. 4). The pattern of labelling was similar to that in free-living Nostoc 7801. The labelling of PE was associated with thylakoid membranes in vegetative cells. There was comparatively little labelling in heterocysts; this is consistent with the fact that heterocysts are generally deficient in phycobiliproteins (see Stewart, 1980). The intensity of labelling was similar in vegetative cells of the cyanobiont and Nostoc 7801. Cyanophycin granules (nitrogen reserves) were also noted in the cyanobiont (see Fig. 1), indicating that the cyanobiont is not nitrogen starved. Considering that the frequency of heterocysts (which have a very low phycobiliprotein content) is eight or nine times higher in the cyanobiont, the overall level of phycobiliproteins would be considerably lower than that of Nostoc 7801. 

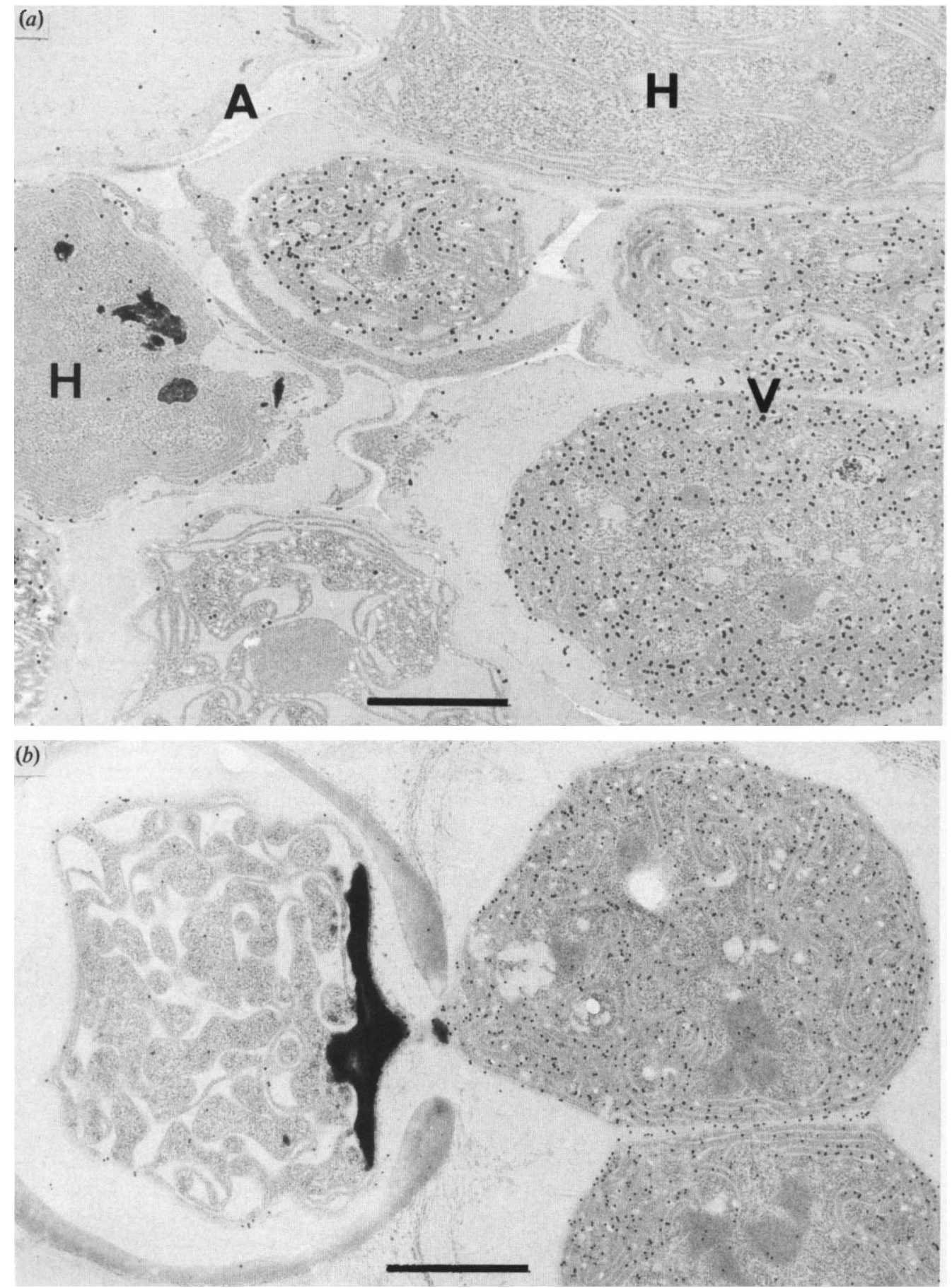

Fig. 4. Localization of PE in the cyanobiont (a) and in the free-living cultured isolate Nostoc $7801(b)$. Rabbit anti-Phormidium percicinum PE was used as primary antibody. Other details as in Figs 1 and 2. 

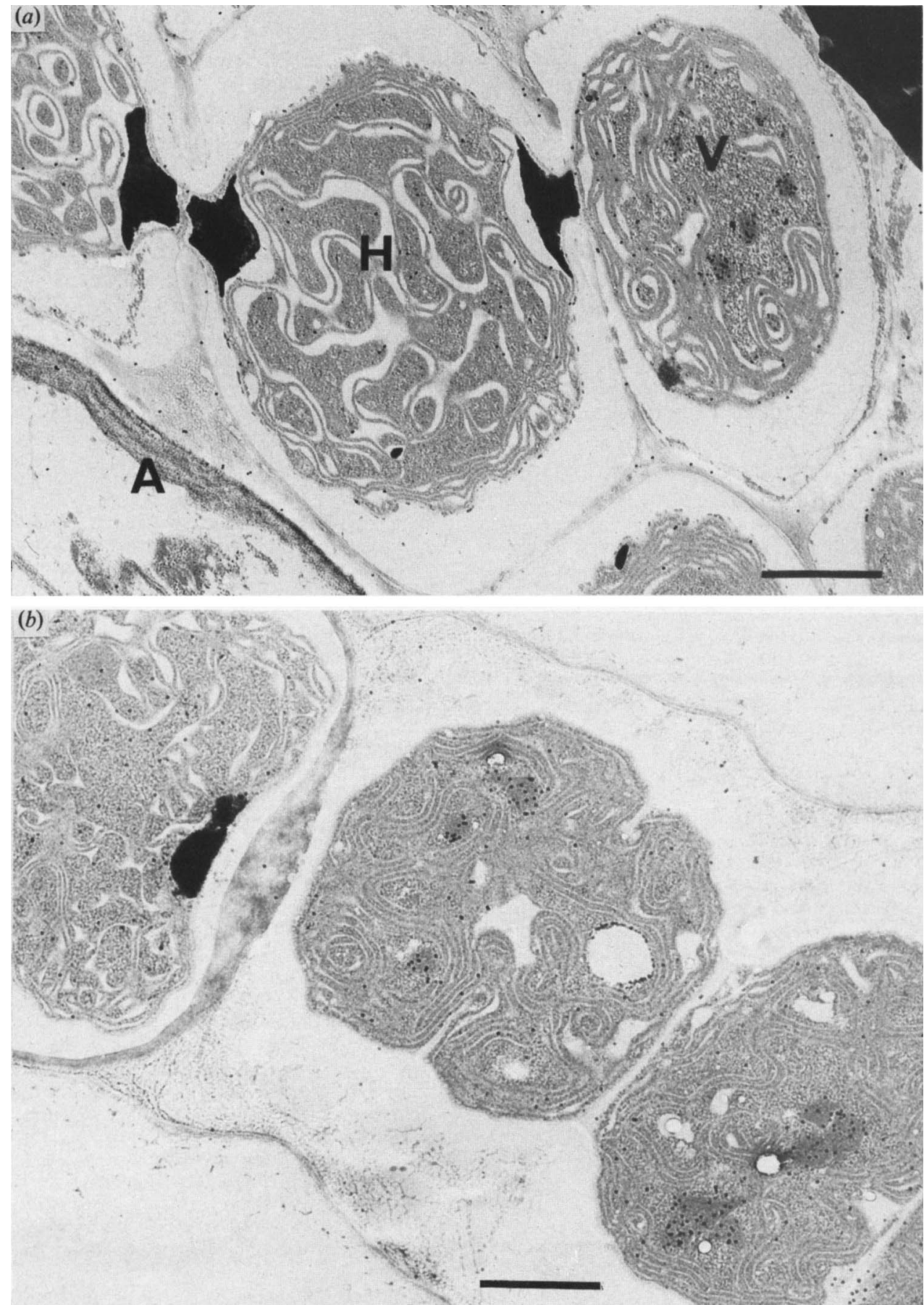

Fig. 5. Localization of $\mathrm{RuBis} C \mathrm{CO}$ in the cyanobiont $(a)$ and in the free-living cultured isolate Nostoc 7801 (b). Rabbit anti-Sinapis alba RuBisCO was used as primary antibody. Other details as in Figs 1 and 2 . 


\section{Ribulose-1,5-bisphosphate carboxylase/oxygenase}

RuBisCO (EC 4.1.1.39) is the primary carboxylating enzyme in cyanobacteria, and cyanobacterial carboxysomes (polyhedral bodies) contain RuBisCO (see Codd \& Marsden, 1984). The cyanobiont of Anthoceros punctatus has been shown to be deficient not only in photosynthetic $\mathrm{O}_{2}$-evolution but also in $\mathrm{CO}_{2}$-fixation (Rodgers \& Stewart, 1977).

In both the cyanobiont and the free-living Nostoc 7801, RuBisCO was present in vegetative cells, with little or no labelling in heterocysts (Fig. $5 a, b$ ). This is consistent with the reported absence of $\mathrm{RuBisCO}$ in heterocysts (Codd et al., 1980; Cossar et al., 1985). The labelling within the vegetative cells was most prominent in carboxysomes, although label was also present in the cytoplasm. The pattern of labelling was similar in the cyanobiont and Nostoc 7801. Thus, the inability of the cyanobiont, in $A$. punctatus, to fix $\mathrm{CO}_{2}$ is not due to lack of $\mathrm{RuBisCO}$. In the case of the cycad cyanobiont, in vitro RuBisCO activity is similar to that of the free-living isolate; however, there is no in vivo $\mathrm{CO}_{2}$-fixation by the cyanobiont (Lindblad et al., 1987).

We thank SAREC, the Swedish Natural Science Research Council, the Indian National Science Academy, and the Department of Science \& Technology (Government of India) for financial support. We also thank Dr Angelica v. Hofston for TEM facilities and Annette Axén for technical assistance.

\section{REFERENCES}

Bergman, B., Lindblad, P., Pettersson, A., Renström, E. \& TiberG, E. (1985). Immunogold localization of glutamine synthetase in a nitrogenfixing cyanobacterium, Anabaena cylindrica. Planta 166, 329-334.

Bergman, B., Lindblad, P. \& Rai, A. N. (1986). Nitrogenase in free-living and symbiotic cyanobacteria: immunoelectronmicroscopic localization. FEMS Microbiology Letters 35, 75-78.

CODD, G. A. \& Marsden, W. J. N. (1984). The carboxysomes (polyhedral bodies) of autotrophic prokaryotes. Biological Reviews 59, 389-422.

Codd, G. A., Okabe, K. \& Stewart, W. D. P. (1980). Cellular compartmentation of photosynthetic and photorespiratory enzymes in the heterocystous cyanobacterium Anabaena cylindrica. Archives of Microbiology 124, 149-154.

Cohen-Bazire, G. \& Bryant, D. A. (1982). Phycobilisomes: composition and structure. In The Biology of Cyanobacteria, pp. 143-190. Edited by N. G. Carr \& B. A. Whitton. Oxford: Blackwell Scientific Publications.

Cossar, J. D., Rowell, P., Darling, A. J., Murray, S., Codd, G. A. \& Stewart, W. D. P. (1985). Localization of ribulose 1,5-bisphosphate carboxylase/oxygenase in the $\mathbf{N}_{2}$-fixing cyanobacterium Anabaena cylindrica. FEMS Microbiology Letters 28, 65-68.

ENGLUND, B. (1977). The physiology of the lichen Peltigera aphthosa, with special reference to the bluegreen phycobiont (Nostoc sp.). Physiologia plantarum 41, 298-304.

Flemming, H. \& Haselkorn, R. (1974). The program of protein synthesis during heterocyst differentiation in nitrogen fixing blue-green algae. Cell 3, 159170.

Gallon, J. R. \& Chaplin, J. E. (1987). An Introduction to Nitrogen Fixation, pp. 52-65. London: Cassell Educational Limited.

GuARD-Friar, D., EISENBERG, B. L., EDWARDS, M. R. \& MACCOLL, R. (1986). Immunocytochemistry of cryptomonad biliproteins. Plant Physiology 80, 3842.
Hällbom, L., Bergman, B. \& RAI, A. N. (1986). Immunogold localization of glutamine synthetase in the cyanobiont of the lichens Peltigera aphthosa and Peltigera canina. Lichen Physiology and Biochemistry 1, 27-34.

Ho, K. K. \& Krogman, D. W. (1982). Photosynthesis. In The Biology of Cyanobacteria, pp. 191-214. Edited by N. G. Carr \& B. A. Whitton. Oxford: Blackwell Scientific Publications.

JANAKI, S. \& WolK, C. P. (1982). Synthesis of nitrogenase in isolated heterocysts. Biochimica et biophysica acta 696, 187-192.

JoSEPH, C. M. \& MeEKS, J. C. (1987). Regulation of expression of glutamine synthetase in a symbiotic Nostoc strain associated with Anthoceros punctatus. Journal of Bacteriology 169, 2471-2475.

LiNDBLAD, P. (1987). Nostoc-cycad symbiosis: with emphasis on the cyanobiont, pp. 25-26. PhD thesis, University of Uppsala.

Lindblad, P. \& Bergman, B. (1986). Glutamine synthetase: activity and localization in cyanobacteria of the cycads Cycas revoluta and Zamia skinneri. Planta 169, 1-7.

Lindblad, P., Hällbom, L. \& Bergman, B. (1985). The cyanobacterium-Zamia symbiosis: $\mathrm{C}_{2} \mathrm{H}_{2}$ reduction and heterocyst frequency. Symbiosis 1, 19-28.

LindBlad, P., RAI, A. N. \& BeRGMAN, B. (1987). Cycas revoluta-Nostoc symbiosis: enzyme activities of nitrogen and carbon metabolism in the cyanobiont. Journal of General Microbiology 133, 1695-1699.

MeEKs, J. C., ENDERlin, C. S., Joseph, C. M., Chapman, J. S. \& Lollar, M. W. L. (1985). Fixation of $\left[{ }^{3} \mathrm{~N}\right] \mathrm{N}_{2}$ and transfer of fixed nitrogen in the Anthoceros-Nostoc symbiotic association. Planta 164, 406-414.

MurRy, M. A., Hallenbeck, P. C. \& Benemann, J. R. (1984). Immunochemical evidence that nitrogenase is restricted to heterocysts in Anabaena cylindrica. Archives of Microbiology 137, 194-199.

NierzWicki-Bauer, S. A. \& HaselkorN, R. (1986). Difference in mRNA levels in Anabaena living freely or in symbiotic association with Azolla. EMBO Journal 5, 29-35. 
Oelmüller, R. \& MoHR, H. (1986). Photooxidative destruction of chloroplasts and its consequences for expression of nuclear genes. Planta 167, 106-133.

ORR, J. \& HASELKORN, R. (1982). Regulation of glutamine synthetase activity and synthesis in freeliving and symbiotic Anabaena spp. Journal of Bacteriology 152, 626-635.

RIPPKA, R. \& STANIER, R. Y. (1978). The effects of anaerobiosis on nitrogenase synthesis and heterocyst differentiation by Nostocacean cyanobacteria. Journal of General Microbiology 105, 83-94.

RIPPKA, R. \& WATERBURY, J. B. (1977). The synthesis of nitrogenase by nonheterocystous cyanobacteria. FEMS Microbiology Letters 2, 83-86.

RIPPKa, R., Deruelles, J., Waterbury, J. B., Herdman, M. \& Stanier, R. Y. (1979). Generic assignments, strain histories and properties of pure cultures of cyanobacteria. Journal of General Microbiology 111, 1-61.

Rodgers, G. A. \& Stewart, W. D. P. (1977). The cyanophyte-hepatic symbiosis. I. Morphology and physiology. New Phytologist 78, 441-458.

Rowell, P., Rai, A. N. \& Stewart, W. D. P. (1985). Studies on the nitrogen metabolism of the lichens Peltigera aphthosa and Peltigera canina. In Lichen Physiology and Cell Biology, pp. 145-160. Edited by D. H. Brown. New York: Plenum Press.
Smith, D. C. \& Douglas, A. E. (1987). The Biology of Symbiosis, pp. 93-145. London: Edward Arnold.

SPENCE, D. W. \& SteWART, W. D. P. (1987). Heterocystless mutants of Anabaena 7120 with nitrogenase activity. FEMS Microbiology Letters $\mathbf{4 0}$, 119-122.

Stal, L. J. \& Krumbein, W. E. (1985). Oxygen protection of nitrogenase in the aerobically nitrogenfixing, nonheterocystous cyanobacterium Oscillatoria sp. Archives of Microbiology 143, 72-76.

STEWART, W. D. P. (1980). Some aspects of structure and function in $\mathrm{N}_{2}$-fixing cyanobacteria. Annual Review of Microbiology 34, 497-536.

StewarT, W. D. P. \& LeX, M. (1970). Nitrogenase activity in the blue-green alga Plectonema boryanum strain 594. Archiv für Mikrobiologie 73, 250-260.

Stewart, W. D. P. \& Rodgers, G. A. (1977). The cyanophyte-hepatic symbiosis. II. Nitrogen fixation and the interchange of nitrogen and carbon. New Phytologist 78, 459-471.

Stewart, W. D. P., Rowell, P. \& Rai, A. N. (1983). Cyanobacteria-eukaryotic plant symbioses. Annales de microbiologie 134B, 205-228. 